\title{
A Study of Utility of Teaching Learning Material at Special Training Centers in Gujarat
}

\author{
Dr. Harikrishna Patel ${ }^{1 *}$
}

\section{ABSTRACT}

Special Training Programme (STP), under the National Mission of Sarva Shiksha Abhiyan, is under the provision of RTE Act-2009 to provide age appropriate special training with the help of special training material approved by state education authorities and teaching by regular school teacher or trained Bal Mitras in the school premises or as per the convenience of children. The study is a need based third party survey which focuses on finding the ground reality of the alternative schooling system in Gujarat. The study was conducted by Faculty of Education, Kadi Sarva Vishwavidyalaya, Gandhinagar. STP being an alternative schooling programme lacks some of the essential schooling infrastructural facilities and so in such case the use of TLM becomes very essential for proper study. The present paper presents the study of the utility of the Teaching Learning Material (TLM) at Special Training Centres (STCs) in Gujarat.

Keywords: Utility, Teaching, Learning, Special Training, Center, Gujarat

Sarva Shiksha Abhiyan is a National Mission for the proliferation of Elementary Education in India. Under Sarva Shiksha Abhiyan (SSA), all the 26 districts and 4 Municipal Corporations in Gujarat are being covered. Suitable changes have been made in the Memorandum of Association of the society to enable it to carry out implementation of projects in the education sector in Gujarat.

Its goals of SSA in the year 2011 were to:

- Open new schools in areas which do not have them and to expand existing school infrastructures and maintenance.

- Address inadequate teacher numbers, and provide training a development for existing teachers

- Provide quality elementary education including life skills with a special focus on the education of girls and children with special needs as well as computer education.

\footnotetext{
${ }^{1}$ Assistant Professor, Vakil Shri D. H. Patel Department of Education, Kadi Sarva Vishwavidyalaya, Gandhinagar *Responding Author

(c) 2016 I H Patel; licensee IJIP. This is an Open Access Research distributed under the terms of the Creative Commons Attribution License (http://creativecommons.org/licenses/by/2.0), which permits unrestricted use, distribution, and reproduction in any Medium, provided the original work is properly cited.
} 
Sarva Siksha Abhiyan is given the grant of thousands crores of rupees by the Govt. of India for the purpose of spread, research and development in the field of Primary Education. The SSA Mission has developed some unique educational models at the primary education level like Building As Learning Aid (BALA), Pragna (a unique model on the concept of Activity Based Learning -ABL), Integrated Education Development (IED) for Special Children and also Special Training Programme (STP) - an Alternative Schooling Programme for the Dropped Out and Out of School Children (OoSC).

Special Training Programme is under the provision of RTE Act-2009 to provide age appropriate special training with the help of special training material approved by state education authorities and teaching by regular school teacher or trained Bal Mitras in the school premises or as per the convenience of children.

The present study is a Need Based Study of SSA which was conducted to do survey from 450 Special Training Centres of the 8 selected districts by SSA out of all the 26 districts of Gujarat. In these selected 450 STCs the present research is an endeavour to study of the impact of Special Training Programme in terms of the coverage of the children, attendance and achievement of children, availability and utility of infrastructural facility, the competency of Bal Mitras, learning pattern, classroom interaction, study material and TLM provided by using Survey method with the help of the tools like questionnaire, interview, observation, achievement tests and opinionnaire as main research tools.

\section{OBJECTIVES OF THE RESEARCH:}

The present research was a need based study on the basis of the needs provided by Special Training Department Head Mr. Hitendra Joshi to conduct a research in the selected 8 districts. The objectives of the Present Study were:

- To study the availability and utility of TLM.

\section{METHODOLOGY:}

\section{Coverage:}

The Universe of Study: All the STCs operating in Gujarat state under SSA and the EVs, children and other concerned persons are the Universe of Population for this study.

\section{Sampling:}

Form of the Sample: The present study was conducted to assess the impact of the 10 to 20 month's Non Residential Special Training Programme in Gujarat. Under this particular programme there are 3378 Special Training Centers operating in the 25 districts of Gujarat. The present study, being a Need Based Study of SSA, was conducted to do survey from the 8 selected districts by SSA out of all the 25 districts of Gujarat. From these selected 8 districts, in 6 districts(Gandhinagar, Bhavnagar, Banaskantha, Kutch, Junagadh and Panchmahal) 2 talukas were randomly selected and in Dang district which has only one taluka (Ahwa) so only one 
taluka was selected there and at Ahmedabad Corp. being a very wide area (909 STC - 26.91\% of total STCs) having more than $25 \%$ of all the centers four wards were selected from it. From the list of all the operating Special Training Centres at all the talukas selected the 450 Special Training Centres (as suggested by the STP Dept. of SSA) were selected randomly in proportion with the total number of Special Training Centres operating at the taluka as a sample of the study.

Units of Observation: Children of STCs, Bal Mitras, BRC/CRC, members of SMC, Teachers of regular school and other concerned persons.

\section{Data Collection:}

Source of Data: interviews and discussion with BRC/CRC, members of SMC, Teachers of regular school and other concerned persons, questionnaire and opinionnaire.

Types of Data: Qualitative and quantitative.

\section{Tools:}

The information regarding these tools is as given below:

1.Questionnaire: Specific questions were asked in this tool on availability and utility of TLM, Infrastructural facility, STP material, extra coaching facility, Classroom Interaction, Learning pattern of the children, documentation, grocery and quality of food, drop out children from the STP, mainstreamed children.

2.Opinionnaire: This Opinionnaire was prepared to know the opinions of the concerned persons with the STP about the STP.

\section{Techniques:}

The research invigilators visited all the STCs of the sample and collected the data by using the tools.

\section{DATA ANALYSIS:}

Nature of Data: Qualitative and Quantitative

- Qualitative analysis of the qualitative data was done.

- Data collected by the Field Investigators was analyzed by using the statistical methods of percentage.

\section{Availability and Utility of TLM :}

The information in this context was collected by using the item number 14, 18 and 20 of Questionnaire and its description is as given below: 
Table : Availability and Utility of the TLM

\begin{tabular}{|l|l|}
\hline Name of TLM & Percentage \\
\hline 1. Note Book & $79.60 \%$ \\
\hline 2.Bag & $71.54 \%$ \\
\hline 3.Compass box & $74.56 \%$ \\
\hline 4.Uniform & $24.18 \%$ \\
\hline 5.Slate - Pen & $70.78 \%$ \\
\hline Question & Percentage \\
\hline 1. Are these facilities made regularly available by SSA? & $78.40 \%$ \\
\hline 2. Is the utility of these facilities satisfactory in fulfilling its educational purpose? & $82.62 \%$ \\
\hline
\end{tabular}

The Graphical presentation of above given Table is made in Graph given below:

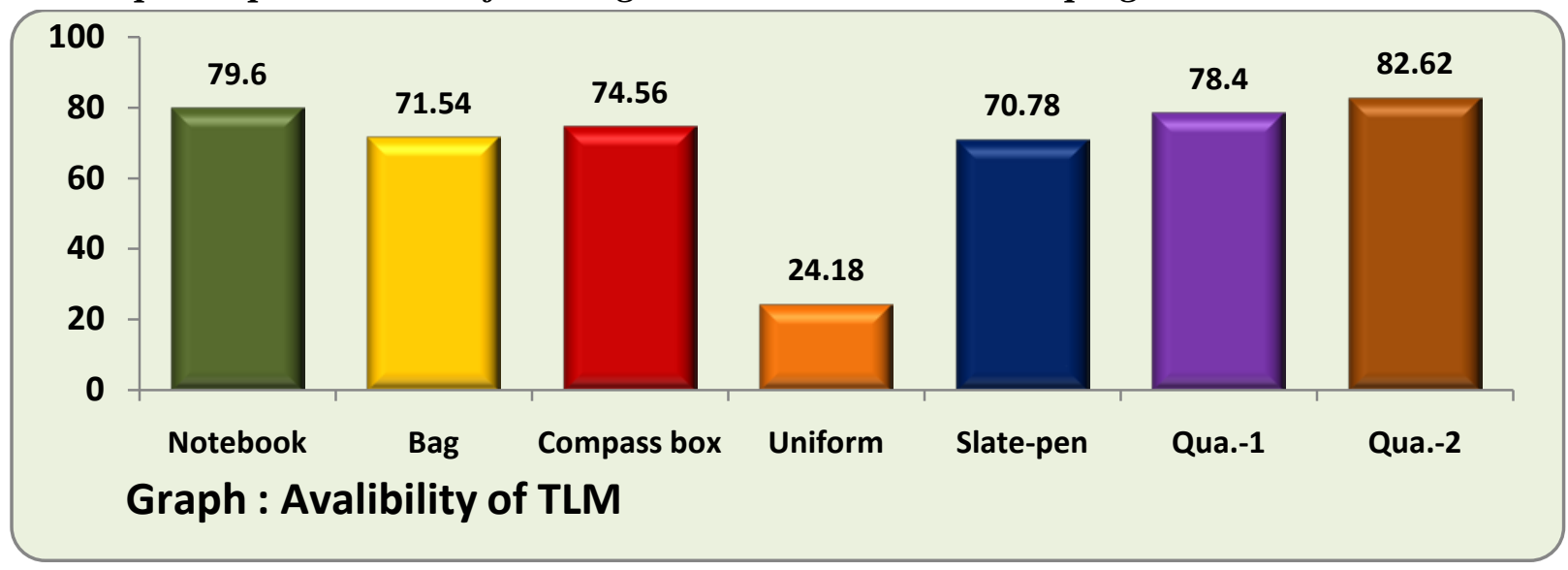

It can be said from observing Table No. - that the facilities of Note book on $79.60 \%$ centres, of Compass box on $74.56 \%$ centres, of Bags on $71.54 \%$ centres, and of Slate - Pen on $70.78 \%$ and of Uniform on $24.18 \%$ centres were available. In these facilities the facility of Notebook was found to be the most available and the facility of Uniform was found to be the least available one.

In reply to the question that 'Are these facilities made regularly available by SSA?' 285 centres means $78.40 \%$ centres replied that these facilities were made available timely by SSA.

In reply to the question that 'Is the utility of these facilities satisfactory in fulfilling its educational purpose?' 312 centres means $82.62 \%$ centres replied that the utility of these facilities were satisfactory in fulfilling its educational purpose.

According to the information collected by item number 15 of tool number 1 regarding the financial assistance, the functioning 397 STC received Rs. 1937 on average to purchase TLM. 


\section{Opinions of Concerned Persons to STP :}

Apart from this the information received by the opinions given by the concern persons to the STP in Opinionative regarding availability and utility of TLM are as given below:

- According to the $81.51 \%$ of the concerned persons the children received the TLM in time.

- According to the $87.40 \%$ of the concerned persons the utility of the TLM was found to be satisfactory for educational purpose.

- In $95.80 \%$ cases the BRC or CRC and in $89.08 \%$ cases the principal or teachers of a school remain present at the time of purchase of TLM for the STC.

\section{FINDINGS :}

- With the financial assistance provided by STP for purchasing the TLM, Notebook was found to be the purchased at most of the STCs (79.60\%) and Uniform was found to be purchased at the least of the STCs (24.18\%).

- According to $78.40 \%$ Bal Mitras and $81.51 \%$ of the concerned persons to STP the TLM was made available in time to the children.

- According to $82.62 \%$ Bal Mitras and $87.40 \%$ of the concerned persons to STP the utility of the TLM was satisfactory for educational purpose.

- According to the Bal Mitras in $95.80 \%$ cases the BRC or CRC and in $89.08 \%$ cases the principal or teachers of a school remained present at the time of purchase of TLM for the STC.

\section{CONCLUSION :}

For purchasing each of these TLM contingency is paid to each of the STCs but still one of the necessary things like uniform was found to be purchased at very few STCs. Although it is not considered as a TLM in many sense but still it should have been purchased if the fund is allotted for this. But overall availability and utility of the TLM at the STCs visited was found to be satisfactory.

\section{REFERENCES}

All India Sample Survey to estimate the number of Out of school children (2009) Social \& Rural Research Institute -IMRB International (SRI-IMRB), 2009

Best, John W. \& James V. Kahn (2009), Research in Education (Tenth Edition), 2009, New Delhi: PHI Learning Private Limited.

Desai, H. G. and K. G. Desai (2010), Research Methods and Techniques (Seventh Edition), University Publication Board, Gujarat Board, Ahmedabad - 5.

Kothari, R.G., Education of Alternative Schooling System in the State of Gujarat (Banaskantha, Panchmahal, Dang districts Gujarat), May - 2003.

Koul Lokesh (2010), Methodology of Educational Research (Fourth Edition). New Delhi, Vikas Publishing House Pvt. Ltd.

Marchant, Amrapali M. (July -2005), Impact of sanitation units on enrolment and retention of Girls in Primary schools”, Ahmedabad. 
Parekh and Trivedi (2010), Statistics in Education (Fifth Edition), University Publication Board, Gujarat Board, Ahmedabad.

Right to Free and Compulsory Education to Children Act, 2009. Balshiksha Nirmulan ane Samaj Ghadatar, Std. 1 to 7 (Teachers' Training Material) Publisher : Sarva Shiksha Abhiyan, Sector - 17, Gandhinagar.

Sarva Shiksha Abhiyan, (Universal Primary Education) Introductory Booklet for the Evaluation of Scheems, Publisher : Gujarat Educational Research and Training Academy, Gandhinagar.

\section{Websites}

> http://www.ssa.tn.nic.in/Schemes-E.htm

$>$ http://gujarat-education.gov.in/ssa/

$>$ http://gujarat-education.gov.in/ssa/information/research_abstracts_14.htm

How to cite this article: H Patel (2016), A Study of Utility of Teaching Learning Material at Special Training Centers in Gujarat, International Journal of Indian Psychology, Volume 3, Issue 3, No. 6, DIP: 18.01.111/20160303 